DOI 10.15393/j9.art.2015.3121

УДК 821.133.1.09-3+821.161.1.09“18“-3

Борис Николаевич Тарасов

Литературный институт имени А. М. Горького

(Москва, Российская Федерация)

bntarasov@yandex.ru

\title{
МЕТАФИЗИКА ДЕНЕГ В ТВОРЧЕСТВЕS БАЛЬЗАКА И ДОСТОЕВСКОГО
}

Аннотация. Автор работы рассматривает сходство и различие в эстетическом истолковании темы денег с точки зрения социального реализма Бальзака и христианского реализма Достоевского. Для решения поставленной задачи вводятся понятия «тайна человека», «темная основа нашей природы», «закон Я», «закон любви». В рамках данных понятий в статье анализируются художественные типы и рефлексия обоих писателей и показываются уравнительная, редукционистская, трансформирующая и компенсирующая функции денежного абсолюта, становящегося всеобщим эквивалентом человеческой свободы и личности и создающего условия для нового неравенства. Автор раскрывает акцентированные в романах русского и французского писателей антропологические последствия доминирования принципов утилитаризма и монетаристского сознания, способствующих искажению и перевертыванию иерархии ценностей, отчуждению и овеществлению взаимоотношений людей, вытеснению из жизни духовно-нравственных начал, энтропии и нигилизму в деградирующем обществе.

Ключевые слова: христианский реализм, «тайна человека», «темный корень бытия», прагматизм, денежный абсолютизм, «закон Я», «закон любви»

$\mathrm{C}$

реди разнообразных факторов, питавших художественную методологию Достоевского, большую роль играло освоение и осмысление им сквозь призму христианства и «реализма в высшем смысле» достижений западной культуры, помогавших ему формировать собственные творческие подходы и раскрывать «тайну человека». Среди европейских писателей, привлекавших его внимание, особое место занимал Бальзак. Он как нельзя лучше отвечал поставленной Достоевским в юности задаче: «...учиться, “что значит человек и жизнь” <...> учить характеры могу из писателей, с которыми лучшая часть жизни моей протекает свободно и радостно...»1. 9 августа 1838 года он писал брату 
Михаилу Михайловичу: «Бальзак велик! Его характеры произведения ума вселенной! Не дух времени, но целые тысячелетия приготовили бореньем своим такую развязку в душе человека» $\left(28_{1}, 51\right)$.

Проявление в духе времени последствий неизменных констант человеческой природы станет одной из основных составляющих художественно-философского мировоззрения писателя, также обозначившегося еще в юности. «Человек есть тайна. Ее надо разгадать, и ежели будешь ее разгадывать всю жизнь, то не говори, что потерял время; я занимаюсь этой тайной, ибо хочу быть человеком», - писал он брату 16 августа 1839 года $\left(28_{1}, 63\right)$.

И неудивительно, что Достоевский не только постигал характеры героев Бальзака в чтении многих его произведений, но и взялся за перевод “Евгении Гранде”. Д. В. Григорович вспоминал: «Когда я стал жить с Достоевским, он только что кончил перевод романа Бальзака «Евгения Гранде». Бальзак был любимым нашим писателем; <...> оба мы одинаково им зачитывались, считая его неизмеримо выше всех французских писателей...»². Сама работа над переводом вызывала у переводчика восторженные чувства. «Нужно тебе знать, писал он в очередной раз брату, - что на праздниках я перевел “Евгению Grandet” Бальзака (чудо, чудо!), перевод божественный...» $(28,86)$.

Разные аспекты влияния Бальзака на творчество Достоевского рассматривались в работах В.С. Нечаевой [14], Г. М. Фридлендера [20], [21], Р. А. Резник [16], Г. Н. Поспелова [15], К. А. Степаняна [17], [18], В. А. Туниманова [19], С. А. Кибальника [13], Л. П. Гроссмана [4], [5], [6] и др.

Тема денег в творчестве Бальзака и Достоевского в исследованиях занимает, как правило, подчиненное место в контексте других общих тем и не рассматривается пристально с точки зрения связи их функционирования с антропологическими основами и духовно-психологическими механизмами, их «невидимого» влияния на укрепление в новых исторических условиях главных сил, говоря словами В. С. Соловьева, «темной основы нашей природы», на энтропию 
и нигилизацию сознания, на оскудение человеческого в человеке и в его взаимоотношениях с другими людьми.

Оба писателя прекрасно понимали значение денег как регулятора социально-экономических аспектов жизни, как универсального эквивалента вложенной энергии и затраченного труда в процессе производства, товарообмена и предоставления услуг, как инструмента материального взаимодействия. Становясь источником вещественного благополучия и комфорта, способствуя удовлетворению утилитарных и прагматических потребностей, деньги вместе с тем как бы незаметно выходят за эти пределы, оказываются неразрывно связанными с социально-психологическими и духовнонравственными сторонами бытия, превращаясь в новое время и во всеобщий эквивалент человеческой свободы, в некую самоцель для достижения престижных статусов, господства и власти с претензией их обладателей, говоря словами Достоевского, на статус «лучших людей», на ведущую роль в развитии цивилизации и создании картины мира, в истолковании смысла истории и назначения человека. Красноречиво подчеркнул эту метафизику и аксиологию монетаристского сознания поэт И. Бродский: «Наравне с землей, водой, воздухом и огнем, - деньги суть пятая стихия, с которой человеку чаще всего приходится считаться. В этом одна из многих, возможно, даже главная причина того, что сегодня, через сто лет после смерти Достоевского, произведения его сохраняют свою актуальность» $[3,1]$.

Вряд ли в этом только состоит главная причина актуальности Достоевского, но проницательное понимание им своеобразной деспотической роли «пятой» стихии на сломе эпох трудно переоценить. Он возводил генеалогию такой роли к Великой французской революции, когда произошло не обновление общества на провозглашенных идеалах, как ожидалось, а лишь «победа одного могучего класса над другим», когда «обновился лишь деспотизм» с негласным девизом: «Убирайся прочь, а я займу твое место». Оказалось, что «новые победители мира (буржуа) еще, может быть, хуже прежних деспотов (дворян) и что “свобода, равенство и братство” оказались лишь громкими фразами и не более. Мало того, 
явились такие учения, по которым, из громких фраз они уже оказались и невозможными фразами. Победители произносили или, лучше, припоминали эти три сакраментальные слова уже насмешливо...» $(23,34)$.

Насмешливость риторического припоминания заключалась в том, что не изменилась, а в лицемерных формах прорвалась, смешивая добро и зло, «темная основа нашей природы», еще более внутренне укрепились принципы эгоцентрического жизнепонимания. «О, конечно, человек всегда и во все времена боготворил матерьялизм и наклонен был видеть и понимать свободу лишь в обеспечении себя накопленными изо всех сил и запасенными всеми средствами деньгами. Но никогда эти стремления не возводились так откровенно и так поучительно в высший принцип, как в нашем девятнадцатом веке. "Всяк за себя и только за себя и всякое общение между людьми единственно для себя” - вот нравственный принцип большинства теперешних людей, [основная идея буржуазии, заместившей собою в конце прошлого столетия прежний мировой строй, и ставшая главной идеей всего нынешнего столетия во всем европейском мире. - Примеч. Достоевского], и даже не дурных людей, a, напротив, трудящихся, не убивающих, не ворующих. А безжалостность к низшим классам, а падение братства, а эксплуатация богатого бедным, - o, конечно, всё это было и прежде и всегда, но не возводилось же на степень высшей правды и науки, но осуждалось же христианством, а теперь, напротив, возводится в добродетель. <...> Наступает, напротив, матерьялизм, слепая, плотоядная жажда тичного матерьяльного обеспечения, жажда личного накопления денег всеми средствами, - вот всё, что признано за высшую цель, за разумное, за свободу вместо христианской идеи спасения лишь посредством теснейшего и братского единения людей» (здесь и далее в цитатах из произведений Достоевского курсив автора. - Б. Т.) $(25,84-85)$.

Подмена идеалов, ослаблявшая духовно-нравственные основы и усиливавшая материально-эгоистические стимулы поведения человека, в ее противопоставленности христианским ценностям осознавалась и Бальзаком, который заключал в «Евгении Гранде»: «Скряги не верят в будущую жизнь, 
для них все - в настоящем. Эта мысль проливает ужасающий свет на современную эпоху, когда больше, чем в какое бы то ни было другое время, деньги владычествуют над законами, политикой, нравами. Установления, книги, люди и учения - всё сговорилось подорвать веру в будущую жизнь, на которую опиралось общество в продолжение восемнадцати столетий. Наша могила - переход, которого мало боятся. Будущее, ожидающее нас по ту сторону Реквиемa, переместилось в настоящее. Достигнуть per fas et nefas (лат.: правдами и неправдами. - Ред.) земного рая роскоши и суетных наслаждений, превратить сердце в камень, а тело изнурить ради обладания преходящими благами, как некогда претерпевали смертельные муки в чаянии вечных благ, такова всеобщая мысль! Мысль, к тому же начертанная всюду, вплоть до законов, вопрошающих законодателя: “Что платишь?" - вместо того, чтобы сказать ему: “Что мыслишь?” Когда учение это перейдет от буржуазии в народ, что станет со страною?» (здесь и далее в цитатах из произведений Бальзака курсив автора. - Б. Т.) ${ }^{3}$.

Подобно Достоевскому Бальзак признавал, что христианство, потерявшее свое значение в современном ему обществе, представляет собой целостную систему подавления порочных стремлений человека, является величайшею основою социального порядка. Однако это признание носило не онтологический и экзистенциальный, а скорее отвлеченный характер и не воплощалось в такой степени, как у Достоевского, в художественных образах и публицистических высказываниях, что отчасти обусловлено «зоологической» доминантой в общей системе его взглядов. В предисловии к «Человеческой комедии» он подчеркивал, что ее идея родилась из сравнения человечества с животным миром, из сопоставления человеческих чувств с животными инстинктами. Считая себя «доктором социальной медицины», проявляя интерес к позитивизму и точным наукам, Бальзак уповал на возможности разума в преодолении «животности» и в совершенствовании личности.

Достоевский также полагал, что человек на земле есть существо только развивающееся и переходное: «Мы, очевидно, 
существа переходные, <..> люди становятся бесами или ангелами» $(11,184)$. По его убеждению, предотвращение падения вниз «к бесам» и движение вверх к «ангелам» невозможно без радикального преображения «темной основы нашей природы». Об этом в статье, посвященной Достоевскому, писал Вл. Соловьев: «Пока темная основа нашей природы, злая в своем исключительном эгоизме и безумная в своем стремлении осуществить этот эгоизм, все отнести к себе и все определить собою, - пока эта темная основа у нас налицо не обращена - и этот первородный грех не сокрушен, до тех пор невозможно для нас никакое настоящее дело и вопрос что делать не имеет разумного смысла. Представьте себе толпу людей слепых, глухих, бесноватых, и вдруг из этой толпы раздается вопрос: “что делать?” Единственный разумный здесь ответ: ищите исцеления; пока вы не исцелитесь, для вас нет дела, а пока вы выдаете себя за здоровых, для вас нет исцеления... Истинное дело возможно, только если в человеке и в природе есть положительные силы добра и света: но без Бога ни человек, ни природа таких сил не имеют» ${ }^{4}$

Достоевского изначально впечатляла неискоренимая двойственность человеческой природы, соединяющей в себе, если воспользоваться известными строками Г. Р. Державина («Я царь, я раб, я червь, я Бог»), царские и рабские, божественные и животные начала. Еще в юности он отметил неизбывное срастание элементов величия и ничтожества человеческого существования, когда во всегда двоящихся картинах мира добро и зло многообразными перепетиями событий и поступков слиты в тесный неразрубаемый узел. «Одно только состоянье и дано в удел человеку: атмосфера души его состоит из слиянья неба с землею, какое же противузаконное дитя человек; закон духовной природы нарушен... Мне кажется, что мир наш - чистилище духов небесных, отуманенных грешною мыслию. Мне кажется, мир принял значенье отрицательное и из высокой изящной духовности вышла сатира» $\left(28_{1}, 50\right)$.

С точки зрения Достоевского, никакие научные теории и достижения социальной медицины не способны исцелить «противузаконное дитя» и вести к его совершенствованию, 
если активна «темная основа нашей природы» и «грешная мысль» искажает «изящную духовность», а «преобладание земли» над «небом» нарушает и «закон духовной природы». Если активна темная основа нашей природы, то ее не преодоленный во Христе грех исключительного эгоизма присваивает и перерабатывает на свой лад любые гуманистические начинания. Сакраментальные вопросы: «что делать?» или «кто виноват?», «что с нами происходит?», задававшиеся не только Чернышевским, Л. Н. Толстым, Лениным, Герценом или Шукшиным, - потому и получают в реальной действительности тупиковые разрешения, что не учитывают подспудного потенциального воздействия ведущих сил не исцеленного «темного корня» бытия. Вместо того чтобы распутывать «клубок» изначальной двусоставности бытия, вызванной первородным грехом, исследовать и преодолевать «незавершенность» (Гр. Нисский), «недосиженность» и «недоделанность» человека, гуманистическая и научная мысль на деле капитулировала перед этими проблемами, удалила их из центра на периферию сознания, отказалась от осмысления бесовско-ангельских следствий в коренной двойственности человеческой природы, от оценки преобладания червиво-рабских ее начал (гордыни, тщеславия, зависти, властолюбия, сластолюбия, сребролюбия, чревоугодия, мстительности и т. п.) над царско-божескими (свобода, любовь, совесть, милосердие, справедливость, честь, достоинство, самопожертвование и т. п.), как бы отрывая человека от Бога, поместив Его в однородный тип натуралистического бытия и одновременно (но нелогично и безосновательно) «по-горьковски» провозгласив, что «человек - это звучит гордо».

Для понимания обозначенной онтологической проблематики, концов и начал Желания и Свободы в представлении Достоевского, их самораскрытия и перехода вверх или вниз, к ангелам или к бесам, чрезвычайно важна запись, сделанная им непосредственно после кончины первой жены:

«Маша лежит на столе. Увижусь ли с Машей?

Возлюбить человека, как самого себя, по заповеди Христовой, - невозможно. Закон личности на земле связывает. 
$Я$ препятствует. Один Христос мог, но Христос был вековечный от века идеал, к которому стремится и по закону природы должен стремиться человек. Между тем после появления Христа, как идеала человека во плоти, стало ясно как день, что высочайшее, последнее развитие личности именно и должно дойти до того (в самом конце развития, в самом пункте достижения цели), чтоб человек нашел, сознал и всей силой своей природы убедился, что высочайшее употребление, которое может сделать человек из своей личности, из полноты развития своего $я$, - это как бы уничтожить это $я$, отдать его целиком всем и каждому безраздельно и беззаветно. И это величайшее счастие. Таким образом, закон я сливается с законом гуманизма $<\ldots .>$ человек есть на земле существо только развивающееся, след<овательно $>$, не оконченное, а переходное. $<\ldots .>$ Итак, человек стремится на земле к идеалу, противуположному его натуре. Когда человек не исполнил закона стремления к идеалу, то есть не приносил любовъю в жертву своего я людям или другому существу (я и Маша), он чувствует страдание и назвал это состояние грехом» $(20,172-173,175)$.

Изучение характеров в произведениях Бальзака давало Достоевскому выразительные примеры того, как деньги «работают» в «темной основе нашей природы», как связаны с усилением червиво-рабских свойств в «законе Я» и ослаблением божественно-царских качеств личности в «законе любви», как содействуют укоренению и тиражированию «ожирелого эгоизма», стремлению брать, а не отдавать и утверждению пороков в качестве добродетелей.

Вернемся к образу скряги, не верящего в бессмертие души и христианское спасение: «Жизнь скряги - постоянное упражнение человеческого могущества, отданного на служение личной выгоде. Скряга опирается только на два чувства - себялюбие и своекорыстие, но так как своекорыстие есть в некотором роде себялюбие, солидное и положительное, непрестанное свидетельство реального превосходства, то себялюбие и своекорыстие - это две стороны одного целого: эгоизма» (Бальзак, 627). 
Для реализации потребностей гордыни, тщеславия, господства, власти, наслаждения и других ведущих сил в «законе Я» в ходе европейских революций формировалась своеобразная и благоприятная общественно-экономическая атмосфера, о которой писал Маркс в «Немецкой идеологии»: «Представляется совершенно нелепым сведение всех многообразных человеческих взаимоотношений к единственному отношению полезности - эта по видимости метафизическая абстракция проистекает из того, что в современном буржуазном обществе все отношения практически подчинены только одному абстрактному денежно-торгашескому отношению <...> У Гольбаха вся деятельность индивидов в их взаимном общении, например речь, любовь и т. д., изображается в виде отношений полезности и использования. Таким образом, действительные отношения, из которых он исходит, - это речь, любовь, определенные действенные проявления определенных свойств индивидов. Но эти отношения не обладают здесь свойственным им специфическим значением, а служат выражением и проявлением некоего третьего, подставленного вместо них, отношения, именно отношения полезности или использования» ${ }^{5}$.

Сведение специфических значений нравственных понятий к отношению полезности или использования при господстве денежно-торгашеского абсолюта, по Достоевскому, лишает эти понятия самостоятельной и активной роли, что способно вести к угасанию высших свойств личности. Мармеладов в романе «Преступление и наказание» говорит Раскольникову: «Господин Лебезятников, следящий за новыми мыслями, объяснял намедни, что сострадание в наше время даже наукой воспрещено и что так уже делается в Англии, где политическая экономия» $(6,14)$. Сам же Лебезятников заявляет: «“Благороднее”, “великодушнее” - всё это вздор, нелепости, старые предрассудочные слова, которые я отрицаю!» $(6,285)$. К «предрассудочным словам» племянник Лебедева относит совесть и честь, заменяя их более точным и реальным, с его точки зрения, понятием здравого смысла.

Своеобразную апологию отношению полезности или использования в «Преступлении и наказании» произносит 
Лужин: «Наука же говорит: возлюби, прежде всех, одного себя, ибо всё на свете на личном интересе основано. Возлюбишь одного себя, то и дела свои обделаешь как следует, и кафтан твой останется цел. Экономическая же правда прибавляет, что чем более в обществе устроенных частных дел и, так сказать, целых кафтанов, тем более для него твердых оснований и тем более устраивается в нем и общее дело. Стало быть, приобретая единственно и исключительно себе, я именно тем самым приобретаю как бы и всем и веду к тому, чтобы ближний получил несколько более рваного кафтана и уже не от частных, единичных щедрот, а вследствие всеобщего преуспеяния. Мысль простая, но, к несчастию, слишком долго не приходившая, заслоненная восторженностью и мечтательностию, а казалось бы, немного надо остроумия, чтобы догадаться...» $(6,116-117)$.

На двусмысленность движения к совокупному преуспеванию через самолюбие и корысть указывает Лужину Разумихин, подчеркивающий, что «общее дело» постоянно «пакостится» скрытым соперничеством и неуемной жадностью его участников, искажением в свой интерес. Предел же этого искажения объясняет Лужину Раскольников: «А доведите до последствий, что вы давеча проповедовали, и выйдет, что людей можно резать...» $(6,118)$.

Обусловленное «законом Я» искажение в свой интерес создавало контраст между материальными достижениями капитализирующего общества и упадком нравственного настроя, понижением духовного уровня личности в нем, усыплением ее божественно-царских свойств. Главный герой романа «Подросток» сокрушается: «Нравственных идей теперь совсем нет; вдруг ни одной не оказалось, и, главное, с таким видом, что как будто их никогда и не было...» $(13,54)$.

«Теперь, - заключает Достоевский, - все действительно хотят счастья <...> Общество не хочет Бога, потому что Бог противоречит науке» $(24,160)$. Однако «счастье» в лоне не просветленной, а по-своему замаскированной и модернизированной «темной основы нашей природы» при господстве «пятой стихии» имеет свою логику развития, которая 
приводит к отчуждению человека от его достоинств и от других людей.

Отчуждение, по представлению Маркса, помимо проче-

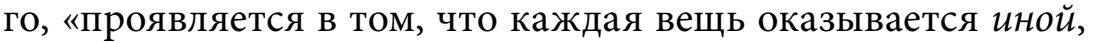
чем она сама, что деятельность оказывается чем-то иным и что, наконец, надо всем вообще господствует нечеловеческая сила» ${ }^{6}$.

Инаковость, то есть несоразмерность восприятия вещей и событий, людей и идей в их подлинной иерархии и ценности и отмеченная ранее перевернутость сознания, обесценивающая божественно-царские свойства личности и возвышающая червиво-рабские, - это и есть проявление дьявольской силы отчуждения и овеществления человеческих отношений.

По заключению М. М. Бахтина, «Достоевский с огромной проницательностью сумел увидеть проникновение этого овеществляющего обесценивания человека во все поры современной ему жизни и в самые основы человеческого мышления» $[1,36]$, в чем и состоял его глубинный смысл борьбы за человеческую душу.

Творчество Бальзака давало русскому писателю много богатых примеров отчуждения и овеществления человеческих отношений, укрепления главных сил «темной основы нашей природы», своеобразного проявления «закона Я» в зоне действия денежно-торгашеского абсолюта и его враждебности по отношению к «закону любви». Французский писатель раскрывает в своих произведениях внутреннюю и объективную логику того, как деньги служат «первородному греху» исключительного эгоизма и извращают природу божественно-царских свойств личности, лишают их специфического значения и делают «инаковыми», поскольку они мешают такому служению.

Так, главный герой повести «Гобсек» живет в атмосфере жизненного позитивизма, «полезности или пользования», подавляя все человеческие чувства для реализации своего жизнепонимания: «если человечность, общение между людьми считать своего рода религией, то его можно было назвать атеистом» (Бальзак, 13). Он сознательно берег жизненную 
энергию, предостерегал себя от великодушных порывов, считая, что на земле нет ничего прочного, а жизнь есть только «машина, которую приводят в движение деньги», только набор условностей, привычка к излюбленной среде, в которой основой всего является инстинкт самосохранения: «в государствах европейской цивилизации этот инстинкт именуется личным интересом» (Бальзак, 15).

Сцепление денег с идеей господства в «законе Я» выражено в главном убеждении Гобсека: «...из всех земных благ есть только одно, достаточно надежное, чтобы стоило человеку гнаться за ним. Это... золото. В золоте сосредоточены все силы человечества <...> человек везде одинаков: везде идет борьба между бедными и богатыми, везде. И она неизбежна. Так уж лучше самому давить, чем позволять, чтобы другие тебя давили. <...> Да и наслаждения повсюду одни и те же, и повсюду они одинаково истощают силы; переживает все наслаждения только одна утеха - тщеславие. Тщеславие! Это всегда наше “я”. А что может удовлетворить тщеславие? Золото! Потоки золота» (Бальзак, 15-16).

Тщеславие самого Гобсека достигает гигантских размеров: «У меня взор, как у Господа Бога: я читаю в сердцах. От меня ничто не укроется. А разве могут отказать в чем-либо тому, у кого в руках мешок с золотом? Я достаточно богат, чтобы покупать совесть человеческую, управлять всесильными министрами через их фаворитов, начиная с канцелярских служителей и кончая любовницами. Это ли не власть? Я могу, если пожелаю, обладать красивейшими женщинами и покупать нежнейшие ласки. Это ли не наслаждение? А разве власть и наслаждение не представляют собою сущности вашего нового общественного строя? Таких, как я, в Париже человек десять; мы властители ваших судеб - тихонькие, никому не ведомые. Что такое жизнь, как не машина, которую приводят в движение деньги? Помните, что средства к действию сливаются с его результатами: никогда не удастся разграничить душу и плотские чувства, дух и материю. 3олото - вот духовная сущность всего нынешнего общества» (Бальзак, 23-24). 
Сама динамика движения к подобному могуществу или определенных достижений на тех или иных этапах к нему, просто существование в создавшейся системе, когда, по словам Бальзака, деньги выражают «нерв жизни нового времени», «сущность всего нынешнего общества», превращаются в своеобразный идол и божество, предполагая особые антропологические метаморфозы, в которых высшие человеческие качества теряют свое специфическое значение и действенность и подчиняются низшим, отчуждая людей друг от друга и превращая их отношения в череду бартерных или торговых сделок. Гобсек, например, уверен, что после тридцати лет человек вообще не может быть честным.

Говоря об извращающей «страшной силе» денег, дьявольски переворачивающей в такой системе человеческие отношения, Маркс писал: «То, чего я как человек не в состоянии сделать, то есть чего не могут обеспечить все мои индивидуальные сущностные силы, то я могу сделать при помощи денег. Таким образом, деньги превращают каждую из этих сущностных сил в нечто такое, чем она сама по себе не является, т. е. в ее противоположность. <..> В качестве этой извращающей силы деньги выступают затем и по отношению к индивиду и по отношению к общественным и прочим связям, претендующим на роль и значение самостоятельных сущностей. Они превращают верность в измену, любовь в ненависть, ненависть в любовь, добродетель в порок, порок в добродетель, раба в господина, господина в раба, глупость в ум, ум в глупость» .

Бальзак многосторонне раскрывает, как теряют свою самостоятельную сущность родительские, родственные, любовные, дружеские отношения, изменяется и искажается значение государственной службы, общественных связей, законов, науки, культуры, искусства и т. д., как деньги успешно эксплуатируют пороки и основные свойства «темной стороны нашей природы».

Гобсек и его, так сказать, коллеги и единомышленники держат под контролем финансовую и судейскую среду, высшее чиновничество и светское общество, золотую молодежь и коммерсантов, актеров и художников. Для своего 
обогащения они используют скорбь, нужды и беды, уязвленное тщеславие и гложущую зависть, обманутые надежды и злостные ухищрения, разочарование и месть, опрометчивость и глупость, стремление к роскоши и суетному престижу, карточные долги и растраты, банкротство и вдовство и т. п.

Гобсек проводит смотр всем страстям и порокам, заглядывает в сокровенные глубины человеческого сердца, проникает во все побудительные причины человеческих действий, раскрывает наготу жизни. «Словом, я владею миром, не утомляя себя, а мир не имеет надо мною ни малейшей властИ» (Бальзак, 17).

Для осуществления такой жизненной стратегии не нужны, более того, мешают и становятся антисистемными «великодушные порывы», справедливость, честь, честность, достоинство, совесть, милосердие и другие божественно-царские свойства личности, поскольку они не покупаются и не продаются, а тем самым не вписываются в систему, теряют свое специфическое содержание и значение, свою сущность и превращаются в свою противоположность.

В обозначенной системе координат возникают естественные для нее, а на самом деле противоестественные чувства: Гобсек никого не желал видеть из родни, ненавидел наследников, ему нравилось унижать людей («графиня стала моей рабой»), «пачкать грязными башмаками» ковры богачей. «Как и я, мои собратья всем насладились, всем пресытились и любят теперь только власть и деньги ради самого обладания властью и деньгами» (Бальзак, 24). Они чувствуют себя богами, когда на их весах взвешиваются наслаждения и корыстные интересы всего Парижа, когда перед ними проходят со своими просьбами, мольбами и слезами якобы независимые аристократы, спесивые купцы, великолепные красавицы, гордые военные, когда они заносят в свою «черную книгу» сведения о государственных кредитах, банках, торговле и в качестве «духовников биржи» образуют своего рода «трибунал священной инквизиции».

Как и для Гобсека, для отца героини романа Бальзака «Евгения Гранде» деньги стали единственным мерилом всего 
существующего, началом и концом бытия. Автор романа задается вопросом: «Не был ли он воплощением единственного божества, в которое верит современный мир?» (Бальзак, 576). Как бы отвечая на этот вопрос, автор говорит о страшном уделе человека, если его жизнь ограничивается материальными интересами.

Единственное божество, под сенью которого сформировалась личность Феликса Гранде, подавляет и извращает человеческие чувства и лишает их специфического содержания. Так, весть о самоубийстве брата оставляет его совершенно равнодушным, а к судьбе осиротевшего племянника он не испытывает ни сострадания, ни родственного участия, быстро сплавляет лишнего нахлебника в Индию. Жену и дочь Феликс Гранде держит в черном теле, лишая их самого необходимого, экономя даже на визитах к врачу. В смерти жены его трогают лишь вопросы наследства, в дочери он видит хранительницу состояния, которая на том свете должна ответить за правильное использование денег.

Социал-дарвинистская атмосфера, возникающая в результате сведения всего к отношению полезности и использования, лишения специфического значения божественноцарских свойств личности и действия переворачивающей силой денег для удовлетворения исключительного эгоизма как «темного корня» человеческой природы, красноречиво выражена в наставлениях, полученных Шарлем Гранде в светском обществе, в понимании жизни как различных комбинаций и сделок. Для достижения выгоды, успехов и возвышения в этих корыстных комбинациях необходимо «не верить ни во что - ни в чувства, ни в людей, ни даже в события <..> каждое утро взвешивать кошелек друга, уметь дипломатически поставить себя выше всего, что происходит <..> ничем не восхищаться - ни созданиями искусства, ни благородными деяниями и движущею силою во всем считать личную выгоду» (Бальзак, 647).

И хотя Шарль был прекрасен своей наивностью и неопытностью, семена меркантильного эгоцентризма успешно проросли в его сердце и дали соответствующие плоды. От вечной мысли о наживе оно сжалось и иссохло, стало черствым 
и алчным в «пьянящем честолюбии», потеряно представление о справедливом и несправедливом, порочном и добродетельном. Смекнув, что лучшим способом разбогатеть является торговля людьми, он перестал быть щепетильным в отношении человеческих прав, продавал китайцев, негров, детей, артистов и соединял такую продажу со сбытом ходовых товаров. При этом оргии с красавицами всех цветов и разных стран стерли в его сознании чистый и благородный образ Евгении Гранде, которая стала занимать место в его мыслях лишь как кредитор. Любовь он считает химерой и намеревается вступить в брак с нелюбимой женщиной, что дает ему возможность получить необходимые титулы и, соединив их с собственным богатством, достигнуть видного и привилегированного положения в обществе.

В образе дяди Шарля Феликса Гранде Бальзак особо подчеркивает связь денежного могущества с гордыней, властолюбием и тщеславием как ведущих свойств «закона Я» в «темной основе нашей природы». Своим богатством он вызывал чувство почтительного восхищения и страха, испытывал постоянную потребность вести игру с людьми, законным порядком добираясь до их денег. «Внушить почтение другому - разве это не значит проявить власть, непрестанно присваивать себе право презирать существа слабые, которые здесь, на земле, отдают себя на растерзание? О, кто же действительно понял агнца, мирно лежащего у ног божьих, трогательнейший прообраз всех жертв земных, прообраз их будущего - словом, страдание и слабость, вознесенные в славе? Этому агнцу скряга дает откормиться, ставит его в загон, убивает, жарит, ест и презирает. Деньги и презрение к людям питают силу скряги» (Бальзак, 145).

Своеобразным агнцем предстает в романе его героиня: «...весь облик ее был облагорожен кротостью христианского чувства, просветляющего женщину и придающего ей тонкую душевную прелесть <... Для нее богатство не было ни властью, ни утешением; она могла жить только любовью, религией, верой в будущее. Любовь объяснила ей вечность. Собственное сердце и Евангелие были для нее два желанных мира» (Бальзак, 599, 698). 
Однако эта женщина не от мира среди мира, отчасти вышедшая из оков «темной основы природы», из-под влияния «закона Я», созданная для величия супруги и матери, но не получившая ни мужа, ни детей, ни семьи, была вынуждена, заключает Бальзак, служить надеждам честолюбия и радостям эгоизма других людей. «Это благородное сердце, бившееся только для нежнейших чувств, должно было, однако, подчиниться расчетам людского корыстолюбия. Деньгам суждено было сообщить свою холодную окраску этой небесной жизни и заронить в женщине, которая вся была чувство, недоверие к чувствам» (Бальзак, 718).

На распутье между материальными успехами богатства и сохранением своей подлинной личности стоит в романе «Отец Горио» Эжен Растиньяк. Молодой человек из бедной семьи приехал в Париж изучать право с целью «приспособить свое образование к будущему развитию общественного строя», с желанием преуспеть в жизни и выдвинуться с помощью светских дам, чтобы утолить безмерно разраставшееся честолюбие. Для побед «на поле битвы парижской цивилизации» необходимо было расстаться с искренними чувствами и непосредственными реакциями, все хладнокровно рассчитывать. Практические советы, подобные тем, которые получил Шарль в «Евгении Гранде», Растиньяку дает виконтесса де Босеан: «Исследуйте всю глубину испорченности женщин, измерьте всю степень жалкого тщеславия мужчин <...> Наносите удары беспощадно, и перед вами будут трепетать. Смотрите на мужчин и женщин, как на почтовых лошадей, гоните, не жалея, пусть мрут на каждой станции, - и вы достигнете предела в осуществлении своих желаний <..> Перестав быть палачом, вы превратитесь в жертву» (Бальзак, 293-294). Здесь можно вспомнить логику Гобсека, делящего людей на давящих (силой денег) и давимых (без них).

Такие советы дополняются рекомендациями Вотрена спешно обрести миллион в социальной среде, где честным быть невыгодно, где все пожирают друг друга, как пауки в банке, где все продается и покупается, а «блеск гения» втаптывается в грязь. «Продажность - всюду, талант - 
редкость. Поэтому продажность стала оружием посредственности, заполонившей все, и острие ее оружия вы ощутите везде» (Бальзак, 317).

Мысли о ненависти посредственности к «блеску гения» и о продажности как орудии посредственности по-своему отражена, как увидим далее, и в романах Достоевского.

Сам Вотрен торговлей неграми («черный капитал») намерен добиться уважаемого положения в обществе, несмотря на свое разбойничество. "Когда же я разбогатею, меня не спросят: “Кто ты такой?” Я буду господин Четыре Миллиона, гражданин Соединенных Штатов» (Бальзак, 318).

Растиньяку «мир <...> предстал теперь таким, каков он есть: в бессилии своей морали и закона перед богатством; ultima ratio mundi (лат.: последняя основа мира. - Ред.) виделась ему в деньгах. "Прав Вотрен. Богатство - вот добродетель!” (Бальзак, 295-296).

Атмосфера произведений Бальзака и логика поведения созданных им типов раскрывают корыстно-эгоистические принципы функционирования денежно-торгашеского абсолюта в лоне «темной основы нашей природы». Эти принципы связаны с оскудением и выхолащиванием духовного мира человека и перевертыванием его отношений с другими людьми в искаженной иерархии ценностей, что позволяет французскому писателю сделать вывод о том, что человек живет в период «великой страшной болезни».

Данные процессы осмыслены у Достоевского уже не в рамках эмпирико-психологического и социально-бытового метода, как у Бальзака, а с точки зрения христианского реализма и применительно к становлению в России новых капиталистических тенденций. С беспокойством отмечал он, что никогда ранее в России не принимали «золотой мешок» за высшее на земле, что «никогда еще он не возносился на такое место и с таким значением, как в наше время», когда поклонение деньгам и стяжание захватывает все вокруг и когда наибольший авторитет приобретают торговцы, юристы и т. п. «лучшие люди». Достоевский полагал, что развратительнее подобного поклонения не может быть ничего и, как и Бальзак, страшился за судьбу своей страны. 
Свое беспокойство Достоевский выражал и в «Дневнике писателя», и в подготовительных материалах к романам, и в самих художественных произведениях. Так, «идиотизм» князя Мышкина в «Идиоте» провоцирует выход на поверхность всех скрытых намерений других персонажей и обнаружение подлинного краха мнимой, солидарной «нормальности» той жизни, в которой он оказался и которая движется в границах «темной основы нашей природы», на стыке развития практических земных интересов. «Нелепость» и «непрактичность» нового героя, его «безумное» пренебрежение собственными интересами, непосредственность и искренность, незащищенность и доверчивость при неспособности лгать и остром проницательном и глубоком уме косвенно выступают своеобразным евангельским эквивалентом, выраженном в словах: «...Бог избрал немудрое мира, чтобы посрамить мудрых, и немощное мира избрал Бог, чтобы посрамить сильное» (1 Кор. 1:27). Более того, появление князя в пореформенной России среди нарождающихся капиталистов и ростовщиков, разного рода авантюристов и дельцов, поклоняющихся золотому тельцу и служащих мамоне, обнажают сами основы «естественного» порядка, предельными выражениями которого становятся смерть и апокалиптическое состояние мира.

Многие персонажи «Идиота» одержимы разрушительной страстью наживы, которая принижает и опускает их души. «Здесь ужасно мало честных людей, - замечает тринадцатилетний Коля Иволгин в разговоре с Мышкиным, - так, даже некого совсем уважать $<. .>$ И заметили вы, князь, в наш век все авантюристы! И именно у нас, в России, в нашем любезном отечестве. И как это так всё устроилось - не понимаю. Кажется, уж как крепко стояло, а что теперь? <...> Родители первые на попятный и сами своей прежней морали стыдятся. Вон, в Москве, родитель уговаривал сына ни перед чем не отступать для добывания денег; печатно известно <...> Bce ростовщики, все сплошь до единого!» $(8,113)$.

Действительно, появляясь в богатом особняке Епанчиных или скромном доме Иволгиных, в мрачном жилище Рогожина или на вечеринке у Настасьи Филипповны, главный герой 
сталкивается с неуемным стремлением к приобретательству, заменяющим или даже искажающим чисто человеческие желания и высшие свойства личности. Генерал Епанчин представляет собой тип сановника-капиталиста, участвует в откупах и акционерных компаниях, имеет два дома в Петербурге и фабрику, «слывет человеком с большими деньгами». Новое амплуа генерала заставляет его и в замужестве собственной дочери видеть выгодную сделку, помогать стареющему сановнику Тоцкому «продать» его грехи Гане Иволгину. Последнему же нужны деньги, чтобы реализовать амбиции своей самолюбивой, тщеславной и посредственной натуры, что, по сути, иллюстрирует слова Маркса об извращающей функции денег, которые заменяют и восполняют отсутствующие сущностные силы индивида, компенсируя его духовную несостоятельность и пустоту. «Я <... прямо с капитала начну, - откровенничает он с Мышкиным, чрез пятнадцать лет скажут: “Вот Иволгин, король иудейский” <..> Нажив деньги, знайте, - я буду человек в высшей степени оригинальный. Деньги тем всего подлее и ненавистнее, что они даже таланты дают <...> Меня Епанчин почему так обижает? <...> Просто потому, что я слишком ничтожен. Ну-с, а тогда...» $(8,105)$. А тогда вступает в действие обозначенная выше логика Вотрена, когда с миллионами в кармане любая посредственность становится уважаемым человеком и может поступать с другими людьми, как ей заблагорассудится.

Коварная сила денег тяготеет и над Рогожиным, в купеческом роде которого с фанатическим изуверством наживали капитал. «А ведь покойник, - говорит он, - не то что за десять тысяч, а за десять целковых на тот свет сживывал» $(8,12)$. У самого Парфена Рогожина стремление к наживе соседствует с чувственной страстью. Ради ее насыщения и удовлетворения себялюбивой алчности он готов перекупить Настасью Филипповну за сто тысяч, сделав свое чувство предметом торга и превратив любовь в ее противоположность. И когда она бросает эти деньги в огонь, в присутствующих обнажаются низкие чувства «темной основы нашей природы»: Лебедев вопит и ползет в камин, Фердыщенко 
предлагает «выхватить зубами одну только тысячу», Ганя падает в обморок и даже князь Мышкин заявляет, что он тоже миллионер, получил наследство и готов предложить руку героине.

Наступление низшего на высшее, золотого тельца на истинную любовь, когда христианский идеал отступает перед мамоной, а предметом купли-продажи становятся красота и человеческое достоинство, создает в романе "убийственную атмосферу». Его персонажи часто обращаются к газетным известиям, к текущей уголовной хронике, например, к делу купца Мазурина, зарезавшего ювелира Калмыкова, или студента Горского, убившего в доме купца Жемарина шесть человек, и Данилова, который ограбил и убил ростовщика Попова и его служанку. Такой финал предсказывают Настасье Филипповне, его предчувствует и она сама, разгадывая тайну «мрачного скучного» рогожинского дома. Разоблачая черное корыстолюбие Гани, Настасья Филипповна оценивает общее поветрие и предполагает, что «этакой за деньги зарежет! Ведь теперь их всех такая жажда обуяла, так их разнимает на деньги, что они словно одурели. Сам ребенок, а уж лезет в ростовщики!» $(8,167)$.

Во второй части Бурдовский выдает себя за незаконного сына Павлищева, благодетеля, получившего наследство Мышкина, и затевает против последнего тяжбу ради собственного обогащения, а его приятель Келлер размещает в газете клеветническую статью о князе. Наблюдая компанию шантажистов, которые, опираясь на извращающую и компенсирующую силу денег «дальше нигилистов ушли», Лизавета Прокофьевна Епанчина в полном согласии с мыслью автора, приходит к предельному выводу: «...уж и впрямь последние времена пришли <..> Теперь мне всё объяснилось. Да этот косноязычный разве он не зарежет (она указала на Бурдовского, смотревшего на нее с чрезвычайным недоумением)? Да побьюсь об заклад, что зарежет! Он денег твоих, десяти тысяч, пожалуй, не возьмет <...> а ночью придет и зарежет, да и вынет их из шкатулки. По совести вынет! <...> Тьфу, всё навыворот, все кверху ногами пошли <...> Сумасшедшие! Тщеславные! В Бога не веруют, в Христа не веруют! 
Да ведь вас до того тщеславие и гордость проели, что кончится тем, что вы друг друга переедите, это я вам предсказываю. И не сумбур это, и не хаос, и не безобразие это?» $(8,237-238)$.

Как и во всем позднем творчестве, Достоевский в «Идиоте» сводит социально-нравственный кризис к религиозному, к потере веры, в результате чего торжествует «темная основа нашей природы», а человеком управляют гордыня и алчность, властолюбие и сластолюбие, подпитываемые денежно-торгашеским абсолютом и изнутри разлагающие возводимые на пьедестал юридические институты, превращая судей в «нанятую совесть». Так, в «Идиоте» Лебедев взялся защищать за обещанное вознаграждение не жертву, а обокравшего ее ростовщика. Другой адвокат пытался убедить свидетелей, что мысль убить естественно должна была прийти на ум бедному преступнику, и гордился про себя, что высказывает самую гуманную и справедливую идею. Рогожин же не противоречит своему ловкому и красноречивому адвокату, лицемерно доказывавшему, что преступление было результатом воспаления мозга. Такой диапазон извращения понятий и возвышенно лживой казуистики сокращает, отодвигает на задний план представление о человеке как об образе и подобии Божием и тем самым как бы закрепляет «низкие причины» его поведения, говоря словами Лизаветы Прокофьевны, «хождения кверху ногами». Когда выносится за скобки разговор о совести и нравственной ответственности человека, создается и маскируется преступная и «убийственная» атмосфера жизни, а правовые ценности лишаются своего специфического содержания и превращаются в свою противоположность, одновременно обогащая «биржевиков» и «юристов», подобных описанным в «Идиоте».

Конечно же, Достоевский не был отрицателем правовых отношений и отдавал должное их относительным достоинствам. Вместе с тем он прекрасно понимал, что их нельзя принимать за панацею, поскольку, инкорпорируясь в «темной основе нашей природы», они вольно или невольно саморазрушаются.

По убеждению Достоевского, вследствие изначальной слабости и порочности человека «закон» неизбежно и крайне необходим (особенно в историческом контексте деспотизма и беззакония). Однако без «благодати» и «даров Божиих», 
без чистого сердца и настоящей свободы, то есть внутренней независимости от особо акцентированного Бальзаком своекорыстия, он таит в себе возможность саморазложения и не имеет никаких преград для поиска «законного» беззакония и удовлетворения глубинных позывов «темной основы нашей природы», следовательно, «прямо перескочить на право силы».

Отмеченные выше антропологические особенности функционирования денег по-своему претворены и в романе «Подросток», где автор показывает разложение родовых, семейных и общественных связей в капитализирующейся России.

Предметом художественного анализа становится неготовность или, как часто выражался Достоевский, «недоделанность» целомудренной в своей основе, но уже испорченной общей жизненной атмосферой и господством денежно-торгашеского абсолюта души Подростка, ищущего справедливости на неправедных путях, в поле действующих сил, говоря словами Вл. Соловьева, «исключительного эгоизма».

В образе Аркадия Долгорукого рельефно воплощена пульсация «темной основы нашей природы», в границах которой направленность воли, особенности характера и своеобразие навязчивой «идеи» соотносятся друг с другом в неразрывном целостном единстве. В подготовительных материалах к произведению автор подчеркивал: «ОЧЕНЬ ВАЖНОЕ. Подросток во весь роман не покидает своей идеи о Ротшильде окончательно. Эта idea fixа есть выход изо всего, из всех вопросов и затруднений. Она основана на чувстве гордости, формулировавшейся в идее уединения $<\ldots>$ Во всем романе вести так, чтобы придать этой идее значение в романе главнейщее» $(16,105-106)$. Затруднения, униженность и оскорбленность юноши обострили в нем эгоистическую гордыню, которая сызмальства впитывалась в его переживания: «...с самых первых мечтаний моих, то есть чуть ли не с самого детства, я иначе не мог вообразить себя как на первом месте, всегда и во всех оборотах жизни» $(13,73)$.

Когда же воображаемое не совпадает с действительностью, уязвленное самолюбие заставляет Подростка отъединиться от тех, кто как-либо превосходит его. Вообще он не любит людей, общение с которыми становится для него 
тяжелым занятием чуть ли не с двенадцатилетнего возраста и от которых он все больше замыкается «в свою скорлупу», как черепаха, уходит в свой угол, погружается в свою идею: «Нет, мне нельзя жить с людьми <...> Моя идея - угол» (13, 48). Но, живя в «скорлупе», в «углу», в «идее», Аркадий Долгорукий не может полностью отъединиться от людей, поскольку он связан с ними своей эгоистической гордыней, стремлением к первенству и господству над ними.

В условиях новых общественных отношений наиболее подходящим средством для одновременного отчуждения, возвышения и господства служили деньги. «Богатство, - отмечал Достоевский в записной книжке, - усиление личности, механическое и духовное удовлетворение, стало быть, отъединение личности от целого» ${ }^{8}$. Поэтому именно богатые люди, особенно процветавшие в Америке, пленили воображение Подростка, когда он мечтал по ночам об отъединенном от людей могуществе над ними: «К себе, к себе! Все порвать и уйти к себе! <...> В Америку! К себе, к одному себе! Вот в чем вся “моя идея”» $(13,60)$.

Свойственное «темной основе нашей природы» и выражающееся в разных формах эгоцентрического сознания «к себе», механически восполняющего и умножающего индивидуальные сущностные силы, ассоциируется в уме Подростка с фигурой Ротшильда, ибо, «пожелав им стать <...> я уже тем самым разом выхожу из общества», - думает он $(13,66)$. Он считал, что такой выход из общества может позволить ему взять верховную власть и признается, что жаждал могущества всю свою жизнь (эта жажда, как известно, снедала и бальзаковского Гобсека).

Пример ничем не ограниченного своеволия, тайной «механической» силы, способной через денежное могущество править миром, Аркадий Долгорукий находит в образе «пушкинского скупого рыцаря», который напоминает Гобсека, готового купить все на свете. «Скупой рыцарь» и сравнивает себя с демоном, которому «все послушно», он же - ничему. Тайное мечтание непослушного демона, злато которого 
впитало в себя кровь и слезы людей, находит высшее наслаждение в том, что он может принудить, поработить и использовать противоположное его духу - добродетель, вольный гений, муз и т. п.

Сердечные грезы настраивают Подростка на аналогичное наслаждение: «Мне нравилось ужасно представлять себе существо, именно бесталанное и серединное, стоящее перед миром и говорящее ему с улыбкой: вы Галилеи и Коперники, Карлы Великие и Наполеоны, вы Пушкины и Шекспиры, вы фельдмаршалы и гофмаршалы, и вот я - бездарность и незаконность, и все-таки выше вас, потому что вы сами этому подчинились» $(13,76-77)$.

Следует заметить, что ротшильдовская идея на первый взгляд неожиданно, но, по сути, закономерно, несмотря на разницу содержания, перекликается с шигалевской идеей в «Бесах», поскольку обе не только игнорируют божественно-царские свойства личности, но и подчиняют их рабскочервивым, находя опору и поддержку в «темной основе нашей природы». Петр Верховенский так характеризует шигалевскую идею, в реализации которой предполагалось великого гения погасить еще в младенчестве, привести всех к «одному знаменателю» и полному «равенству» (как это делают на свой лад деньги): «Шигалев гениальный человек! <..> У него хорошо в тетради <..> Цицерону отрезывается язык, Копернику выкалываются глаза, Шекспир побивается каменьями - вот шигалевщина!..» $(10,322)$. Примечательно, что в обоих случаях, несмотря на разницу в «капиталистической» и «социалистической» логике, наблюдается своеобразная «игра на понижение», обеспечивающая завистливое устремление тех, кто был «ничем», стать «всем». «В том-то и “идея” моя, в том-то и сила ее, что деньги - это единственный путь, который приводит на первое место даже ничтожество» $(13,74)$, так характеризует Аркадий Долгорукий еще одну сторону своего выбора, как бы солидаризируясь в этом пункте с Ганей Иволгиным.

Достоевский неоднократно подчеркивал открывшуюся в новых общественных отношениях возможность посредственности с «миллионом в кармане» первенствовать 
и обесценивать в них духовно-нравственные аспекты, вообще делать все, что угодно. «Когда можно делать всё что угодно? - вопрошает Достоевский в “Зимних заметках о летних впечатлениях”. - Когда имеешь миллион. Дает ли свобода каждому по миллиону? Нет. Что такое человек без миллиона? Человек без миллиона есть не тот, который делает всё что угодно, а тот, с которым делают всё что угодно» $(5,78)$. Писатель особо выделил в подготовительных материалах к роману «Подросток» привлекательность для молодого человека перевертывающей и компенсирующей функции этого свойства его «идеи»: «Его, главное, утешает в его системе наживы - бесталанность ее. Именно то, что не нужно гения, ума, образования, а в результате все-таки - первый человек, царь всем и каждому и может отмстить всем обидчикам» $(16,46)$.

В «Подростке» встречается своеобразное рассуждение владельца ссудной кассы Стебелькова о перемене ролей в обновленном обществе: «Я - второй человек. Есть первый человек, и есть второй человек. Первый человек сделает, а второй возьмет. Значит, второй человек выходит первый человек, а первый человек - второй человек <...> Была во Франции революция, и всех казнили. Пришел Наполеон и всё взял. Революция - это первый человек, а Наполеон - второй человек. А вышло, что Наполеон стал первый человек, а революция стала второй человек. Так или не так?» (13, 181-182). Продолжая аналогию Стебелькова, можно сказать, что развитие истории делало Наполеонов - вторыми, а Ротшильдов - первыми людьми.

В черновиках Достоевский «характеризует идею Ротшильда» как новое явление и «неожиданное свойство нигилизма» в обществе без оснований и преданий, теряющем религиозные убеждения и нравственные устои. При воцарившемся «беспорядке» (этим словом первоначально обозначалось название романа) «игра на понижение» становилась естественным соблазном для "вторых», стремившихся стать «первыми» с помощью денег, компенсирующих таланты и обесценивающих божественно-царские свойства личности (ср. выстраданное мнение Гани Иволгина: «Деньги тем всего подлее и ненавистнее, что они даже таланты дают» $(8,105))$. 
Общее поветрие хождения «кверху ногами» захватывает и Аркадия Долгорукого, противоречиво и парадоксально сочетаясь в его юношеской душе с жаждой высшего порядка и духовного благообразия. Автор подчеркивает, что он «ищет руководящую нить поведения, добра и зла, чего нет в нашем обществе, этого жаждет он, ищет чутьем, и в этом цель романа (курсив мой. - Б. Т.)» $(16,51)$. В этих поисках Подросток сталкивается с самыми разными проявлениями «беспорядка» в семейных и социальных отношениях, попадает в водоворот неожиданных и катастрофических происшествий и переносит тяжелые нравственные испытания, в результате которых его «идеи» теряют над ним свою притягательную власть, но руководящая нить так и не обретается, хотя на путь познания добра и зла он уже вступил, оставаясь, как и Эжен Растиньяк в «Отце Горио», на распутье.

Произведения Бальзака давали Достоевскому материал для осмысления их проблемности уже не на социально-бытовом и эмпирико-психологическом уровне, а на духовном, в плане познания «тайны человека», его двойственности и потенциальной переходности к «бесам» или «ангелам».

Для изображения всего комплекса идей, связанных c «тайной человека» и выявлением в его ценностях, мыслях и чувствах, поведении и деятельности признаков «закона Я» и «закона любви», движения по направлению к «бесам» или «ангелам» требовался особый художественный метод, который в работах В. Н. Захарова [10], [11], И. А. Есаулова [7], [8], [9], К. А. Степаняна [19], [20], Т. А. Касаткиной [12] и ряда других исследователей характеризуется как христианский реализм, а сам Достоевский называл «реализмом в высшем смысле»: «Меня зовут психологом: неправда, я лишь реалист в высшем смысле, то есть изображаю все глубины души человеческой» $(27,65)$. И еще одно самоопределение: «При полном реализме найти в человеке человека. Это русская черта по преимуществу, и в этом смысле я конечно народен (ибо направление мое истекает из глубины христианского духа народного)» $(27,65)$.

М. М. Бахтин подчеркивал: «Достоевский сделал дух, то есть последнюю смысловую позицию личности предметом 
эстетического созерцания... Он продвинул эстетическое видение вглубь - высоту сознания» $[2,313]$. Именно сосредоточенность на последней смысловой позиции и глубинных пластах сознания, где происходит невиданное противоборство «закона Я» и «закона любви», «счастья» и «величайшего счастья», «земли» и «неба», «грешной мысли» и «духов небесных», «бесов» и «ангелов» превращает «пневматолога» Достоевского в своеобразного стратегического мыслителя на все времена, рассматривавшего основные проекты развития мира «без Бога» и «с Богом», в сопряжении признаков ничтожества и величия в мистерии человеческого существования.

Формула «найти в человеке человека» включает в себя, по крайней мере, три взаимосвязанных аспекта. Во-первых, это то сердечно-волевое ядро личности, в котором зарождаются доминантные качества ее Желания и Свободы, предопределяющие ее движения к «закону Я» или «закону любви». Вовторых, найти человека в человеке значит разглядеть в его «падшести» и «восстановить лик человеческий». Наконец, в-третьих, это есть «угадывание» фазиса его будущего развития, ибо человек «не исчерпывается днем настоящим», на основе проникновения в борения его доброй и злой воли.

По Достоевскому, на самой глубине человеческого духа скрыт самый главный вопрос: кто есть человек - продукт стихийной игры слепых сил природы, «свинья естественная», как утверждает, например, Ракитин в «Братьях Карамазовых» и подобные ему персонажи в других романах, или образ и подобие Божие? Если человек со всеми своими духовными устремлениями и нравственными страданиями принимается за мышь, пусть и «усиленно сознающую мышь» (так выражается герой «Записок из подполья»), тогда открывается широкое поле для доминирования «закона Я», развития червиво-рабских свойств личности, образования в очевидных или замаскированных формах социал-дарвинистской атмосферы, подавляющей в себе божественно-царские черты.

И напротив, если человек воспринимает себя как образ и подобие Божие, тогда он удовлетворяет глубинную, более или менее осознанную потребность в не теряемом со смертью смысле своего существования. А все специфически 
человеческие, божественно-царские свойства личности, слитые с действенной памятью о Первообразе и его заповедях, становятся, по Достоевскому, не внешней условностью, а внутренней силой, способной устанавливать разницу между «счастием» и «величайшим счастием», преодолевать природный плен биологического отбора, превозмогать иго натуральных страстей, гедонистических склонностей, властных притязаний, сложившейся конъюнктуры, своекорыстных расчетов, - словом, тех свойств в «законе Я», которые в разной степени, форме и пропорциях торжествуют в миропредставлении и жизненных ориентациях «усиленно сознающей мысли» и вносят катастрофические элементы энтропии, дисгармонии и разлада во взаимоотношения людей. По его неизменному убеждению, от смутно ощущаемого или явно сознаваемого ответа на главный вопрос о собственной сущности, с разной степенью отчетливости и вменяемости дающий о себе знать, зависит вольное или невольное предпочтение определенных ценностей, направление воли и желаний, та психологическая доминанта, которая в конечном итоге предусматривает и активизирует идейный выбор или конкретный рисунок жизни, судьбу отдельной личности, целого народа, всего человечества.

Эта основополагающая альтернатива жизни «с Богом» и «без Бога» неразрывно соединяет в художественно-философском подходе Достоевского элементы антропологии, историософии, эсхатологии и обыденной жизни. В раздумьях о «тайне человека», как бы соединяя проблемы религии и высокой метафизики с ходом эмпирической истории и конкретной деятельностью людей, писатель определяет вопрос «о необходимости понятия бессмертия души для человеческого прогресса» как «роковой и вековечный». «Представьте себе, - пишет он в письме к Н.Л. Озмидову в феврале 1878 года, - что нет Бога и бессмертия души (бессмертие души и Бог - это всё одно, одна и та же идея). Скажите, для чего мне тогда жить хорошо, делать добро, если я умру на земле совсем? Без бессмертия-то ведь всё дело в том, чтоб только достигнуть мой срок, и там хоть всё гори. А если так, то почему мне (если я только надеюсь на мою ловкость и ум, 
чтоб не попасться закону) и не зарезать другого, не ограбить, не обворовать, или почему мне если уж не резать, так прямо не жить за счет других, в одну свою утробу?» $\left(30_{1}, 10\right)$.

В историческом процессе вообще и на каждом его этапе в частности Достоевский обнаруживает тот же самый фундаментальный парадокс, что и в душе отдельного человека: сознательное, бессознательное или даже воинственное, насильственное забвение идеального измерения бытия в «законе любви» и божественного происхождения человека при одновременно автоматически необходимой опоре на так называемые «реалистические» основания в «законе Я», здравый смысл или разумный эгоизм, экономическую выгоду или утилитарную мораль умаляют высшие смысловые цели существования людей, ослабляют их связи с землей и друг с другом. Тогда место абсолютного идеала как гаранта Цели и Смысла занимают его суррогаты и идолы, «деревянные, златые или мысленные», по словам одного из персонажей, появляется обманчивая вера в науку, деньги, прогресс, в построение очередной Вавилонской башни, социального муравейника, превращающегося в курятник, хрустального дворца, оборачивающегося «парикмахерским развитием».

Подобные метаморфозы и снижающие, вульгаризирующие исторические модификации в логике писателя как бы заранее запрограммированы так, что любой «естественный» изобретенный эмансипированным разумом идеал всегда оказывается поверхностным и грубым, не только не просветляет «темную основу нашей природы», но зачастую маскирует, утончает и усиливает ее энтропийные свойства, а потому попытки его реализации не только не прерывают, а нередко и разветвляют цепочки господствующего в мире зла и безумия. Он заключал, что общество имеет предел своей деятельности, тот забор, на который оно наткнется и остановится из-за нравственной деградации в социокультурном устройстве.

В произведениях Бальзака и в ходе самой жизни Достоевский усматривал выстраивание такого забора, поскольку принципы утилитаризма и прагматизма и коррелирующие с ними воздействия денежно-торгашеского абсолюта постепенно способствовали (неважно вольно или невольно, 
сознательно или бессознательно) как бы расщеплению двойственной природы человека, отсоединению божественноцарских свойств личности от червиво-рабских, укреплению в замаскированных формах зловредного корня «исключительного эгоизма» и ослаблению влияния высших христианских ценностей, единственно способных исцелить его.

По убеждению Достоевского, отвратить отдельную личность, целый народ или все человечество от перспективы наткнуться на забор и остановиться может лишь жизнь «с Богом». Только абсолютный идеал, его духовная высота, нравственная глубина и смыслополагающая сила способствуют исцелению «исключительного эгоизма» падшей человеческой природы, стирают в душе все остальные идеалы и идолы и позволяют людям не довольствоваться собственной греховной природой в «законе Я» и стремиться к ее преображению, очищают корыстолюбивые, разрушительные побуждения натуры и переводят их в созидательно-человеческую плоскость.

Таким идеалом, создающим непосредственность и непобедимость ощущения высшей красоты и подлинной духовной гармонии, делающим благодатный отказ от «неаккуратных» движений собственной воли от «счастия» К «величайшему счастию» добровольным и естественным, была для писателя личность Христа, Богочеловека с его совершенной любовью, которая является выражением предельной свободы и одновременно величайшим самостеснением, победой над созданной Адамом «натурой» с ее «законом Я». По его убеждению, только христоподобная любовь (и бо́льшая или меньшая способность вместить ее в очищающееся сердце), которая не завидует, не гордится, не превозносится и «не ищет своего», ибо не отождествляется ни с какими корыстными интересами «исключительного эгоизма», дающая, а не берущая любовь, которая долготерпит и все переносит, способна преобразить «темную основу нашей природы», возвысить и облагородить отуманенную «грешною мыслию» (включающую и денежный абсолют) душу человека, восстановить перевернутую иерархию ценностей. 


\section{Примечания}

* Публикация подготовлена в рамках поддержанного РГНФ научного проекта № 15-34-11091а (ц).

${ }^{1}$ Достоевский Ф. М. Полное собрание сочинений: в.30.т. Л.: Наука, 1972-1990. Т. 28. Кн. 1. С. 63. Далее ссылки на это издание приводятся в тексте статьи с указанием тома, книги (нижний индекс) и страницы в круглых скобках.

${ }^{2}$ Григорович Д. В. Литературные воспоминания. М.: Гослитиздат, 1961. C. 87.

${ }^{3}$ Бальзак О. Собрание сочинений: в 10 т. М.: Художественная литература, 1982-1987. Т. 2. С. 624. Далее: Бальзак. Ниже ссылки на это издание приводятся в тексте статьи с указанием страницы в круглых скобках.

${ }^{4}$ Соловьев Вл. Сочинения: в 2 т. М.: Мысль, 1988. Т. 2. С. 311.

${ }^{5}$ Маркс К., Энгельс Ф. Сочинения: в 39 т. 2-е изд. М.: Изд-во политической литературы, 1955. Т. 3. С. 409-410.

${ }^{6}$ Маркс К., Энгельс Ф. Из ранних произведений. М.: Госполитиздат, 1956. C. 608.

${ }^{7}$ Там же. С. 619-620.

${ }^{8}$ Ф. М. Достоевский об искусстве. М.: Искусство, 1973. С. 460.

\section{Список литературы}

1. Бахтин М. М. Проблемы поэтики Достоевского. - М.: Советский писатель, 1963. - 167 с.

2. Бахтин М. М. Эстетика словесного творчества. - М.: Искусство, 1979. $-424 \mathrm{c}$.

3. Бродский И. Власть стихий. О Достоевском. Деньги [Электронный pecypc]. - URL: http://www.mymoney.pro (10.08.2015).

4. Гроссман Л. П. Бальзак // Гроссман Л. П. Библиотека Достоевского: по неизданным материалам. С приложением каталога библиотеки Достоевского. - Одесса: Книгоизд-во А. А. Ивасенко, 1919. С. 27-63.

5. Гроссман Л. П. Бальзак в переводе Достоевского // Бальзак О. Евгения Гранде. / пер. Ф. М. Достоевского. Ред. и коммент. Л. П. Гроссмана. - М.; Л.: «Academia», 1935. - C. IX-XXXVII.

6. Гроссман Л. П. Поэтика Достоевского. - М.: Гос. Акад. художественных наук, 1925. - 188 с.

7. Есаулов И. А. О сокровенном смысле «Станционного смотрителя» А. С. Пушкина // Проблемы исторической поэтики. - Петрозаводск: ПетрГУ, 2012. - Вып. 10: Евангельский текст в русской литературе XVIII-XX веков: цитата, реминисценция, мотив, сюжет, жанр. Вып. 7. - С. 25-30. 
8. Есаулов И. А. Христианский реализм как художественный принцип Пушкина и Гоголя // Четвертые Гоголевские Чтения: Гоголь и Пушкин. - М.: Книжный дом «Университет», 2005. - С. 100-108.

9. Есаулов И. А. Христианский реализм как художественный принцип русской классики // Феномен русской духовности. - Калининград: РГУ имени И. Канта, 2007. - С. 9-20.

10. Захаров В.Н. Проблемы исторической поэтики: этнологические аспекты. - М.: Индрик, 2012. - 256 с.

11. Захаров В.Н. Христианский реализм в русской литературе (постановка проблемы) // Проблемы исторической поэтики. - Петрозаводск: ПетрГУ, 2001. - Вып. 6: Евангельский текст в русской литературе XVIII-XX веков: цитата, реминисценция, мотив, сюжет, жанр. Вып. 3. - С. 5-20.

12. Касаткина Т. А. О творящей природе слова: онтологичность слова в творчестве Ф. М. Достоевского как основа «реализма в высшем смысле». - М.: ИМЛИ им. А. М. Горького РАН, 2004. - 480 с.

13. Кибальник С. A. «Eugénie Grandet» О. де Бальзака в переводе Достоевского // Достоевский и мировая культура. Альманах № 29. - СПб.: Серебряный век, 2012. - С. 27-40.

14. Нечаева В. С. Ранний Достоевский. 1821-1849. - М.: Наука, 1979. $288 \mathrm{c}$.

15. Поспелов Г. Н. «Eugénie Grandet» Бальзака в переводе Ф. М. Достоевского // Ученые записки института языка и литературы. - М., 1928. - T. II. - C. 103-136.

16. Резник Р. А. Достоевский и Бальзак // Реализм в зарубежных литературах XIX-XX веков. - Саратов: Изд-во Саратовского ун-та, 1975. - Вып. 4. - С. 153-203.

17. Степанян К. А. «Сознать и сказать»: «реализм в высшем смысле» как творческий метод Ф. М. Достоевского. - М.: Раритет, 2005. - 512 с.

18. Степанян К. А. Человек в свете «реализма в высшем смысле» (Достоевский, Шекспир, Сервантес, Бальзак, Маканин) // Вопросы философии. - 2014. - № 5. - С. 98-103.

19. Туниманов В. А. Отзвуки романа О. Бальзака «Отец Горио» в творчестве Ф. М. Достоевского // Художественное сознание и действительность: межвузовский сборник / Санкт-Петербургский гос. университет; ред. А. Г. Березина. - СПб.: Изд-во Санкт-Петербургского университета, 2004. - С. 302-322.

20. Фридлендер Г. М. Реализм Бальзака. - М.: Наука, 1964. - 371 с.

21. Фридлендер Г. М. Реализм Достоевского. - М.; Л.: Наука, 1964. - 404 c. 
Boris N. Tarasov

The Maxim Gorky Literature Institute

(Moscow, Russian Federation)

bntarasov@yandex.ru

\title{
METAPHYSICS OF MONEY IN THE WORKS OF HONORÉ DE BALZAC AND FYODOR DOSTOEVSKY
}

\begin{abstract}
The author examines similarities and differences in the aesthetic interpretation of the theme of money in terms of social realism of Balzac and Christian realism of Dostoevsky. Such notions as "human mystery", "a dark side of human nature", the "ME law", "the law of love" are introduced to achieve the aforementioned objective. As part of these notions, the article analyzes artistic types and reflection of both writers and shows the equalizing, reducing, transforming and compensating functions of the monetary absolute, which becomes a common equivalent of human freedom and personality and creates conditions for a new inequality. The author reveals anthropologic consequences caused by dominating principles of utilitarianism and monetarist perception, highlighted in the novels by French and Russian writers, that facilitate perversion and inversion of a hierarchy of values, displacement of spiritual and moral fundamentals, mental impoverishment, entropy and nihilism in the degrading society.
\end{abstract}

Keywords: Christian realism, human mystery, the dark root of existence, pragmatism, the monetary absolute, the ME law, the law of love

\section{References}

1. Bakhtin M. M. Problemy poetiki Dostoevskogo [The problems of poetics of Dostoevsky]. Moscow, Sovetskiy pisatel' Publ., 1963. 167 p.

2. Bakhtin M. M. Estetika slovesnogo tvorchestva [Aesthetics of Verbal Art]. Moscow, Iskusstvo Publ., 1979. 424 p.

3. Brodskiy J. Vlast' stikhiy. O Dostoevskom. Den'gi [The power of Nature. About Dostoevsky. Money]. Available at: http://www.mymoney.pro (accessed 10 August 2015).

4. Grossman L. P. Bal'zak [Balzac]. Biblioteka Dostoevskogo: Po neizdannym materialam. S prilozheniem kataloga biblioteki Dostoevskogo [The library of Dostoevsky: based on the unpublished materials. With the catalogue of Dostoevsky's library]. Odessa, Knigoizdatel'stvo A. A. Ivasenko Publ., 1919, pp. 27-63.

5. Grossman L. P. Bal'zak v perevode Dostoevskogo [Balzac in translation by Dostoevsky]. Bal'zak O. Evgeniya Grande. Per. F. M. Dostoevskogo. Red. i komment. L. P. Grossmana [Balzac H. Eugénie Grandet, translated 
by F. M. Dostoevsky, edited and commented by L. P. Grossman]. Moscow; Leningrad, Academia Publ., 1935, pp. IX-XXXVII.

6. Grossman L. P. Poetika Dostoevskogo [Dostoevsky's poetics]. Moscow, State Academy of Art Sciences Publ., 1925. 188 p.

7. Esaulov I. A. O sokrovennom smysle «Stantsionnogo smotritelya» A. S. Pushkina [About an inmost meaning of The Stationmaster by A. S. Pushkin]. Problemy istoricheskoy poetiki [The problems of historical poetics]. Petrozavodsk: Petrozavodsk State University Publ., 2012. Vol. 10: Evangel'skiy tekst $v$ russkoy literature XVIII-XX vekov: tsitata, reministsentsiya, motiv, syuzhet, zhanr [The Gospel text in Russian Literature of the 18th-20th Centuries: quotation, reminiscence, motive, plot, genre]. Issue 7, pp. 25-30.

8. Esaulov I. A. Khristianskiy realizm kak khudozhestvennyy printsip Pushkina i Gogolya [Christian realism as an artistic principle of Pushkin and Gogol]. Chetvertye Gogolevskie Chteniya: Gogol'i Pushkin [The Fourth Gogol Readings: Gogol and Pushkin]. Moscow, The Book house University Publ., 2005, pp. 100-108.

9. Esaulov I. A. Khristianskiy realizm kak khudozhestvennyy printsip russkoy klassiki [Christian realism as an artistic principle of Russian classical literature]. Fenomen russkoy dukhovnosti [A phenomenon of Russian spirituality]. Kaliningrad, Immanuel Kant Baltic Federal University Publ., 2007, pp. 9-20.

10. Zakharov V. N. Problemy istoricheskoy poetiki: Etnologicheskie aspekty [The problems of historical poetics: ethnological aspects]. Moscow, Indrik Publ., 2012. 256 p.

11. Zakharov V. N. Khristianskiy realizm $\mathrm{v}$ russkoy literature (postanovka problemy) [Christian realism in Russian literature (setting of a problem]. Problemy istoricheskoy poetiki [The problems of historical poetics]. Petrozavodsk: Petrozavodsk State University Publ., 2001. Vol. 6: Evangel'skiy tekst $v$ russkoy literature XVIII-XX vekov: tsitata, reministsentsiya, motiv, syuzhet, zhanr [The Gospel text in Russian Literature of the 18th-20th Centuries: quotation, reminiscence, motive, plot, genre]. Issue 3, pp. 5-20.

12. Kasatkina T. A. O tvoryashchey prirode slova: Ontologichnost' slova $v$ tvorchestve F. M. Dostoevskogo kak osnova «realizma v vysshem smysle» [About the creative nature of the word. Word ontology in the creative work of Fyodor Dostoevsky as the basis of "realism in the best sense of the term"]. Moscow, The A.M. Gorky World Literature Institute of the Russian Academy of Sciences Publ., 2004. 480 p.

13. Kibal'nik S. A. «Eugénie Grandet» O. de Bal'zaka v perevode Dostoevskogo ["Eugénie Grandet" by Honoré de Balzac translated by Dostoevsky]. Dostoevskiy i mirovaya kul'tura. Al'manakh № 29 [Dostoevsky and World 
culture. Literary miscellany № 29]. Saint-Petersburg, Serebryanyy vek Publ., 2012, pp. 27-40.

14. Nechaeva V. S. Ranniy Dostoevskiy. 1821-1849 [The early Dostoevsky. 1821-1849]. Moscow, Nauka Publ., 1979. 288 p.

15. Pospelov G. N. «Eugénie Grandet» Bal'zaka v perevode F. M. Dostoevskogo ["Eugénie Grandet" by Honoré de Balzac translated by Dostoevsky]. Uchenye zapiski instituta yazyka i literatury [Bulletin of Institute of Language and Literature]. Moscow, 1928, vol. II, pp. 103-136.

16. Reznik R. A. Dostoevskiy i Bal'zak [Dostoevsky and Balzac]. Realizm $v$ zarubezhnykh literaturakh XIX-XX vekov [Realism in the World literature of the 19th-20th centuries]. Saratov, Saratov State University Publ., 1975, issue 4, pp. 153-203.

17. Stepanyan K. A. "Soznat' i skazat'»: «Realizm v vysshem smysle» kak tvorcheskiy metod F. M. Dostoevskogo [To realize and to say. "Realism in the best sense of the term" as an artistic method of F. M. Dostoevsky]. Moscow, Raritet Publ., 2005. 512 p.

18. Stepanyan K. A. Chelovek v svete «realizma v vysshem smysle» (Dostoevskiy, Shekspir, Servantes, Bal'zak, Makanin) [The man in the light of "realism in the best sense of the term" (Dostoevsky, Shakespeare, Cervantes, Balzac, Macanin)]. Voprosy filosofii [Philosophical issues], 2014, no. 5, pp. 98-103.

19. Tunimanov V. A. Otzvuki romana O. Bal'zaka «Otets Gorio» v tvorchestve F. M. Dostoevskogo [Reminiscence of Balzac's novel "Le Pere Goriot" in the works of F. M. Dostoevsky]. Khudozhestvennoe soznanie i deystvitel'nost': mezhvuzovskiy sbornik [Artistic consciousness and reality: an inter-institutional bulletin]. Saint-Petersburg, Saint Petersburg State University Publ., 2004, pp. 302-322.

20. Fridlender G. M. Realizm Bal'zaka [Realism of Balzac]. Moscow, Nauka Publ., 1964. $371 \mathrm{p}$.

21. Fridlender G. M. Realizm Dostoevskogo [Realism of Dostoevsky]. Moscow; Leningrad, Nauka Publ., 1964. 404 p.

Дата поступления в редакиию: 12.08.2015

(C) Тарасов Б. Н., 2015 